\title{
THE IDEAL EDUCATION IN IBN KHALDUN'S MUQADDIMAH FOR ERADICATING UNEMPLOYMENT THROUGH INTEREST
} AND TALENT

\author{
Anwar Hafidzi \\ Universitas Islam Negeri Antasari \\ E-mail: anwar.hafidzi@uin-antasari.ac.id
}

\begin{tabular}{|c|c|c|}
\hline Received & Revised & Accepted \\
\hline 15 Maret 2020 & 15 April 2020 & 28 September 2020 \\
\hline
\end{tabular}

\begin{abstract}
This article explores the idea that the students are able to understand even though they are not educated or accomplished. Some scholars assume, however, that the educational path must go through classrooms. At least this result will give anyone the potential to enhance strong listening skills. The book Diwan Al-Mubtada Wa Al-Khabar Fi Tarikh Al-'Arab Wa Al-Barbar Wa Man 'Asarahum Min Dzawi Al-Sha'ni Al-Akbar by' Abdurrahman Ibn Khaldun with hermeneutic methodology is study using library study with the key source. The outcomes of this research are the principle of fatqu al-lisan by giving preference to basic education abilities by learning soft skills and hard skills of special interest. Ultimately, this power would add to self-confidence in doing business individually and minimize unemployment.
\end{abstract}

Keywords: education, interest, talent, alleviation, unemployment

\section{Introduction}

The problem with scientific integrity is that scientific dichotomy emerges in education. ${ }^{1}$ Science and technology developments in the world of education and industry continue to advance quickly in the current century. ${ }^{2}$ The development of new ideas is an excellent innovation in social sciences, science and accurate industries. ${ }^{3}$ This is so that people always find the results of more sophisticated

\footnotetext{
${ }^{1}$ Maarten Matheus van Houten, "Vocational Education and the Binary Higher Education System in the Netherlands: Higher Education Symbiosis or Vocational Education Dichotomy?," Journal of Vocational Education \& Training 70, no. 1 (2018): 130-147.

${ }^{2}$ Michael W. Meyer and Don Norman, "Changing Design Education for the 21st Century," She Ji: The Journal of Design, Economics, and Innovation, Design Education. Part I, 6, no. 1 (March 1, 2020): 13, https://doi.org/10.1016/j.sheji.2019.12.002.

${ }^{3}$ Danielle Wilde, "Design Research Education and Global Concerns," She Ji: The Journal of Design, Economics, and Innovation, Design Education. Part II, 6, no. 2 (June 1, 2020): 170, https://doi.org/10.1016/j.sheji.2020.05.003; Yogesh K. Dwivedi et al., "Impact of COVID-19 Pandemic on Information Management Research and Practice: Transforming Education, Work and Life,"
} 
thinking than experiments. This research is inseparable from the integration of knowledge that is qualified to achieve clear goals within the academic world. Is the education system still valid in the academic field only for those who can or cannot go to school ${ }^{4}$.

An interesting point of view at this time is that the material is an important note because the end of a learning is the more respected in the community, ${ }^{5}$ assuming the richer a person is. This issue is the writer's spotlight, since material expectations are the key subject of today's society, it is not shocking that in the future science studies such as medicine, engineering, chemistry, economics are becoming promising education. ${ }^{6}$ Though expensive it has to be redeemed ${ }^{7}$.

The author thought that the book of Diwan Al-Mubtada Wa Al-Khaba Fi Tarikh Al-'Arab Wa Al-Barbar Wa Man 'Asharahum Min Dzawi Al-Sha'ni Al-Akbar, through the Ibn Khaldun study (d. 1412) on Al-Tariqah and Al-Tailim, was an implied response to this need to ensure that the role of education could be played, so that it could compete if society was more beneficial to every individual.

\section{Literature Review}

\section{Social Settings Ibn Khaldun Ibn Khaldun's}

Abu Zaid'Abdurahman ibn Mohammad ibn Muhammad ibn al-Muhammad ibn Jabir ibn Muhammad Ibn ibn al-Abraham ibn Abd Rahman ibn Chaldun is the full name. The complete name of this is Abu Zaid. Khaldun, or rather Ibn Chaldun, was born in Tunisia in the name of Wali al-Ddin, Hadrami al-Tunisia, on 1 Ramadhan 732 H, coincided on 27 May 1332 AD and died in Cairo in 1406 AD. Ibn Khaldun's ancestors came from the Arab community. ${ }^{8}$ Nearly all of his family came from Hadramaut in Yemen, and their family met a fellow Prophet Muhammad, Wail bin Hujr from the tribe of Kindah. Following the loss of Islamic power in Andalusia and the move to the country, the whole of the family made the great grandfather in

\footnotetext{
International Journal of Information Management, July 31, 2020, 102, https://doi.org/10.1016/j.ijinfomgt.2020.102211.

${ }^{4}$ Anis Rahmawati, "Literacy Practice in Vocational Engineering Education: Is It Necessary?(A Case Study on the Concrete Construction Course)," in International Conference on Teacher Training and Education 2017 (ICTTE 2017) (Atlantis Press, 2017).

${ }^{5}$ Imam Suyitno et al., "Teaching Materials and Techniques Needed by Foreign Students in Learning Bahasa Indonesia," ISLLAC: Journal of Intensive Studies on Language, Literature, Art, and Culture 1, no. $1(2017)$ : 52-70.

${ }^{6}$ Stephen Harwood and Sally Eaves, "Conceptualising Technology, Its Development and Future: The Six Genres of Technology," Technological Forecasting and Social Change 160 (November 1, 2020): 160, https://doi.org/10.1016/j.techfore.2020.120174.

${ }^{7}$ Issa I. Salame and Ashley Thompson, "Students' Views on Strategic Note-Taking and Its Impact on Performance, Achievement, and Learning.," International Journal of Instruction 13, no. 2 (2020): 1-16.

${ }^{8}$ Basma Ahmad Sedki Dajani, “The Ideal Education in Ibn Khaldun's Muqaddimah,” Procedia - Social and Behavioral Sciences, The Proceedings of 2nd Global Conference on Conference on Linguistics and Foreign Language Teaching, 192 (June 24, 2015): 308, https://doi.org/10.1016/j.sbspro.2015.06.044; Antar Abdellah and Abdelbaset Haridy, "Medieval Muslim Thinkers on Foreign Language Pedagogy: The Case of Ibn Khaldun,” Lingua 193 (July 1, 2017): 62-63, https://doi.org/10.1016/j.lingua.2017.05.001.
} 
Andalusia Ibn Khaldoun witness the glory of Islam, and the decline of Islamic rule as he was in Spain ${ }^{9}$.

In the 14th century, Ibn Khaldun did not really differentiate between scientific knowledge of religion and science, but everything was arranged by means of basic education and had to be mastered as a methodology ${ }^{10}$. In the end different discipline would emerge, without losing their strength, as servant of God and his goals became the caliph in his path, Ibn Khaldun shrieks that Natural Education was in the form of obedience to the creator.

\section{Basic Discourse}

An amazing and complementary aspect is science that is able to combine faith and general science of its life. When God taught names to the Prophet Adam (as), he learned many things overall and not through His angels. "This is because humans are sent down to Earth with the purpose of knowing God. This objective will certainly not be achieved if only by standing by or surrendering to the development and advancement of information and technology at the moment. But for a better life for the world and the hereafter, too, learn and seek knowledge.

The West wants to think more about Islam's values, which are to continue to explore and build awareness. ${ }^{12}$ The Western Hemisphere is well known for its sophistication and advances in technology, thus demonstrating that advanced and modern claims are naturally pinned to the West. Although this claim actually comes from the Arab Arabs who gave their knowledge and studied by the West once again. Surely this progress is inseparable from Religion which gives enthusiasm in the development of science and technology. This awareness is obtained through the adjustment of their own vision of controlling the country, pursuing wealth, wealth and religion spread. ${ }^{13}$

Religion should be established as a basis for scientific progress, after realizing how significant the role of religion is in human life. It is because there are findings which would be imbalanced if scientific and technical progress is not backed up with the propagation of its religious values. ${ }^{14}$ Thanks to this vacuum, of course, the outcomes obtained would appear arrogant and arbitrary. Do not rule out more evil if you want something to master.

\footnotetext{
9 Ibn Khaldūn, An Arab Philosophy of History; Selections from the Prolegomena of Ibn Khaldun of Tunis. (London: Murray, 1950).

${ }^{10}$ Djamel Chabane, “The Structure of 'Umran al-'Alam of Ibn Khaldun," The Journal of North African Studies 13, no. 3 (2008): 331-349, https://doi.org/10.1080/13629380701844656. See also M. Umer Chapra, “Ibn Khaldun's Theory of Development: Does It Help Explain the Low Performance of the Present-Day Muslim World?," Journal of Socio-Economics 37, no. $2 \quad$ (2008): 836, https://doi.org/10.1016/j.socec.2006.12.051.

${ }^{11}$ Stephen Greenblatt, The Rise and Fall of Adam and Eve (W. W. Norton \& Company, 2017), 12.

${ }^{12}$ David Decosimo, "Political Freedom as an Islamic Value," Journal of the American Academy of Religion 86, no. 4 (2018): 912-952.

${ }^{13}$ Herman L. Beck, "Islam in Indonesia. The Contest for Society, Ideas and Values, Written by Carool Kersten," Bijdragen Tot de Taal-, Land-En Volkenkunde/Journal of the Humanities and Social Sciences of Southeast Asia 172, no. 4 (2016): 571-572.

${ }^{14}$ M. Nasir Budiman and Saifullah Idris, "Between Religion and Education in Freud Perspective," Advanced Science Letters 24, no. 10 (2018): 7090-7094.
} 
In the study of Ibn Khaldun 's book, Ibn Khaldun suggests that science arises from two different perspectives but is mutually complementary. This science is a basis for further development. He uses the term: ${ }^{15}$

The scientific definition is divided into two parts, first of all, based on an actual reality: science which is based on fact, or is called aqli, knowledge obtained from the results of studies using fact-transmitted philosophical approaches. ${ }^{16}$ This group of studies is capable of sorting out the good parts that are regarded as wrong in daily life. This theoretical basis cannot be separated from the use of justification for understanding current truth. ${ }^{17}$ This is what Ibn Khaldun is called because people are characteristically given God's wisdom, but sometimes people do not understand the use of reason provided by the Creator.

Secondly, science is based on the revelation of god, who is for humanity, in the carrying out of their life in the universe. It is an Islamic and religious science family, including Koran research, hadith, philosophy, linguistics and other sciences. In the sense of a closed reasoning ability to mess with the law of God, the only parallel between the main notions and the branches is what is done. Therefore, if explained in detail, it is not possible to restructure the original law.

A combination of elastic constants shows that scientific development has evolved to incorporate a variety of fundamental problems into the regulation of daily life. Eventually, this pattern creates capabilities based on the will of all humans.

\section{Foundation Of Integration: A Research Analysis That Is Able To Boost Economic Efficiency}

Ibn Khaldun tried to chart the convergence of science and religion, as well as the study of the cause and the proposals of revelation in solving the life question. History says the Islamic world 's expert tradition has developed with very proud expertise, such as Al-Khwarizmi or Algorizm (d. 780) AlFadl Ibn Ahmed Altibrizi (d. 923) with expertise in mathematics, algebra, calculus and astronomy. Ibn Sina Avicenna (980-1037) Ibn Rushd Averroes (d. 1128), scientific, metaphysical, mathematical, and astronomical studies. In metal sector Shihabuddin Al Tifashi (d. 1184).Nasir Al-Din Al-Tusi (d. 1274) in the field of astronomy, and many more Muslim scientists who are better known by their scientific fields. ${ }^{18}$

\footnotetext{
${ }^{15}$ Muhammad Ibn Khaldun, Diwan Al-Mubtada Wa Al-Khaba Fi Tarikh Al-'Arab Wa Al-Barbar Wa Man 'Asarahum Min Dzawi Al-Sha'ni Al-Akbar (Lebanon: Dar-Fikr, 1998), 548.

${ }^{16}$ Aminuddin Hassan et al., "The Role of Islamic Philosophy of Education in Aspiring Holistic Learning," Procedia - Social and Behavioral Sciences, WCPCG 2010, 5 (January 1, 2010): 2113, https://doi.org/10.1016/j.sbspro.2010.07.423.

${ }^{17}$ Igor Ivanov, Jesennia Cárdenas Cobo, and Marina Kosonogova, "Implementation of Developmental Education in the Digital Learning Environment," Procedia Computer Science, 9th World Engineering Education Forum (WEEF 2019) Proceedings: Disruptive Engineering Education for Sustainable Development, 172 (January 1, 2020): 517, https://doi.org/10.1016/j.procs.2020.05.062; Juliette Cezzar, “Teaching the Designer of Now: A New Basis for Graphic and Communication Design Education," She Ji: The Journal of Design, Economics, and Innovation, Design Education. Part II, 6, no. 2 (June 1, 2020): 213, https://doi.org/10.1016/j.sheji.2020.05.002.

${ }^{18}$ Philip K. Hitti, History of the Arabs, (Jakarta: Serambi Ilmu, 2006), 548.
} 
According to the historical analysis by Ibn Khaldun, the society will progress because of the rising number of people in the Region. The culture that he meant was a system of education and teaching, as well as an economy that developed with that society. ${ }^{19}$ So it's no surprise that cities are always a measure of the economy of a country, even a lot of people go to cities to boost their economies. Ibn Khaldun 's term is for improving the economic structure that starts with the human system as a social being. The statement by Ibn Khaldun: ${ }^{20}$

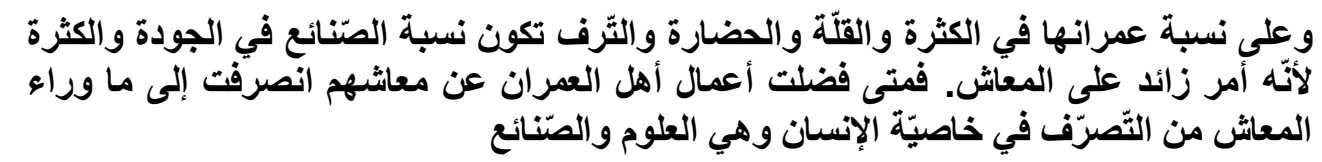

"Indirectly Islam is calling for increased advancement in technology and science through daily life through its role in religious and scientific research. In urban areas, the answer lies in more jobs as the population increases. This competition is driving religious scientists to develop their science for the State's benefit. Ibn Khaldun exemplified this pattern with the term that the teacher was a daily-oriented work of his. Unlike the countryside, where the level of society appears to be sluggish in developing research, this is due to the work done in rural areas that are more like farming and planting as a way of life."

This economic factor was why Ibn Khaldun had a base (al-ashlu) and a branch (al-furu') in the educational position in order to achieve better lives. He claims, however, to have close ties with al-ashlu from religious knowledge in political affairs, urban and rural development and work skills. Ibn Khaldun with the misfortune or ability of reason to learn and to learn is called this integration. If the society has a strong and advanced civilization, science should grow.

History has shown how many Islamic scholars in the science and development of the world were largely influenced by the West. ${ }^{21}$ Improved production is inseparable from specialists in high-rise buildings and those who master technology and architecture. Franz Rosenthal cited the proud of the Arab peoples who were raised with brilliant abilities but then began eroding with civilization. This may combine research and meditation, faith and science, science and reason, both of which are ways of moving closer to the maker. ${ }^{22}$ It now prioritizes the economy and begins to abandon religion as its basis rather than the other way around. That is why Muslims will be proud, as in the Middle Ages it was a golden age that was the past of civilization, although it is now in decline.

\footnotetext{
${ }^{19}$ Anwar Hafidzi, "Dampak Dari Penetapan UU Nomor 26 Tahun 2000 Terhadap Kejahatan Kemanusiaan Dan Genosida Di Indonesia," Syariah: Jurnal Hukum Dan Pemikiran 15, no. 2 (2015).

${ }^{20}$ Ibn Khaldun, Diwan Al-Mubtada Wa Al-Khaba Fi Tarikh Al-'Arab Wa Al-Barbar Wa Man 'Asarahum Min Dzawi Al-Sha'ni Al-Akbar, 549.

${ }^{21}$ Anwar Hafidzi, "Dampak Dari Penetapan UU Nomor 26 Tahun 2000 Terhadap Kejahatan Kemanusiaan Dan Genosida Di Indonesia,” Syariah: Jurnal Hukum Dan Pemikiran 15, no. 2 (2015).

${ }^{22}$ Abdullah Sahin, "Critical Issues in Islamic Education Studies: Rethinking Islamic and Western Liberal Secular Values of Education,” Religions 9, no. 11 (2018): 335.
} 


\section{Result and Discussion}

\section{Intellectual mastery: between knowledge and objectives}

Ibn Khaldun education must be accomplished by fostering morality from an early age together with his parents. Fathers must know how their children conduct themselves and must provide adequate education to their children's situation, so that time does not prevail in their relations. Ibn Khaldun said: ${ }^{23}$

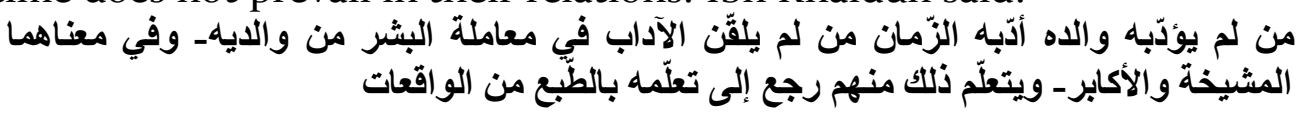

"When there is no early schooling, it would inevitably learn from various social interactions with natural circumstances. If no teacher teaches him, this aspect will influence his logic in his life."

Of course, if there are three teachers in education, namely students, parents, environment. An institution's education is apparent from its experience in the society and its environment. The result of education is definitely positive for the community and the world of work and the world of faith.

Ibn Khaldun says that people are capable of thinking and resolving the problem. To enter a theory, ${ }^{24}$ there are different stages of human rational thinking:

1. al-Tamyizi, that is, to recognize all that happens and to choose within their own capacities through human intellectuals. The form of such thinking is typically a perception that helps people achieve their own livelihoods and rejects anything that is irrelevant to them.

2. Tajriibi, namely the ability to think that humans are complementary to their need for a range of thinking and behaviors. His way of thinking tells the claims that can be made in the process step by step to profit from his experience. That's what Ibn Khaldun called experimental rationality.

3. Nazari, The opportunity to test facts that are already understood by using concrete action to combine 'Ilm (knowledge) and zhann (hypothesis). This is a cause for speculation. Combining the capacity in perception and perception at this level if human beings can combine in this level is the essence of the purpose of the existence of reason throughout the human being, according to Ibn Khaldun.

In fact, he experienced his journey and experience in the levels of reason in Ibn Khaldun 's view. Humans are therefore creatures which believe that the mind can bring about knowledge by being able to think and bring about a better society. Nevertheless Ibn Khaldun emphasized the social culture character (al-tabi 'al-tsaqafi al-ijtima'i), which existed then in scientific and doctrinal development. Lastly, the mind that can adapt to its environment can produce many scientific and innovative skills. Nevertheless, it is still not clear that Ibn Khaldun is realistic in his thought but he puts forward the practical application styles during the learning process in his idea which includes a number of practical skills. The ability of the teacher's learning

\footnotetext{
${ }^{23}$ Ibn Khaldun, Diwan Al-Mubtada Wa Al-Khaba Fi Tarikh Al-'Arab Wa Al-Barbar Wa Man 'Asarahum Min Dzawi Al-Sha'ni Al-Akbar, 140.

${ }^{24}$ Ibn Khaldun, 917.
} 
results shows that reason will develop even further if it continues with complete mastery as specified. Ibn Khaldun said ${ }^{25}$ :

"Indeed, scientific capacity and deep comprehension can be accomplished only by a complete technical mastery of basic concepts, formulas and information and science-related problems."

The ability to think will therefore produce intelligence in science and can be achieved through the ability of people themselves. If this curiosity does not exist, then people cannot use their ability to gain science intelligence and agility.

The consequences of this potential for thought definitely cannot be isolated from other aims, namely by the job, which is the civilization Ibn Khaldun refers to, which would develop if people have the knowledge of technology. It is the center of the economy and a large number of people go to work for the city. Ibn Khaldun makes research a separate piece, where education is based on the will of students. The goal is that students feel happy and get what they aim for the world and the hereafter.

Ibn Khaldun does not deny that it is in the world and after that the objective of education is to be happy. Work was part of education, for in Tunisia at that time it was intended to achieve a good economy and reduce unemployment. In daily life, even political science is performed. He taught the lessons when he was requested to be part of the government, and even the science of communication (fatqul lisan) was skilled in dialogue. All this was derived from his knowledge of his parents and teachers, which he was known for.

\section{Overcoming Joblessness with Training-Ready Skill}

The Statistic Indonesia, known in Indonesia as BPS (or Badan Pusat Statistik, the Central Bureau of Statistics) found that, according to estimates, unemployment was $5.5 \%$ or equals 7.02 million people in Indonesia in 2016. Based on the composition, the unemployment rate is often higher in urban areas than in rural areas. The unemployment rate in February 2017 was 6.50 percent in cities and just 4.0o percent in rural areas. Muhammad Nuh as minister of education, assumed that because of insufficient qualifications, the number of unemployed was. Diploma skills, requisite abilities and maturity of thought are suspected of triggering an educational decline ${ }^{26}$.

As previously explained, education can contribute to the progress of civilization, although civilization in cities is better than in villages. The current structure in the community affects this. The system in the village is more costeffective, and city society is rapidly established because people compete for better materials. This was shown when it was mentioned that economic factors are a part of a civilization 's success. ${ }^{27}$

\footnotetext{
${ }^{25}$ Ibn Khaldun, 158. "Badan Pusat Statistik," June 16, 2020, https://www.bps.go.id/pressrelease/2019/11/05/1565/agustus-2019--tingkat-pengangguran-terbuka-tpt--sebesar-5-28-persen.html.

${ }^{27}$ Anwar Hafidzi, “Konsep Pendidikan Kemasyarakatan Ibnu Khaldun Dalam Kitab Muqaddimah,” 2019.
} 
Ibn Khaldun also tried to practice this talent in different fields he admired. ${ }^{28}$ The importance of an profession varies depending on skills and needs. If the society needs to be high, then the importance of the mission is much higher and much more important, education would be necessary to promote skills. We therefore need skills and basic skills to achieve a better economy.

This study shows more unemployment for those without a permanent job and who usually only collect financials in the wrong way, thefts, players who eventually even reversed the economy of the nation ${ }^{29}$. This understanding is consistent with the economy's key objectives of developing a culture that needs a capable population in various fields of work, as if it were called unemployment. Ibn Khaldun Said ${ }^{30}$ :

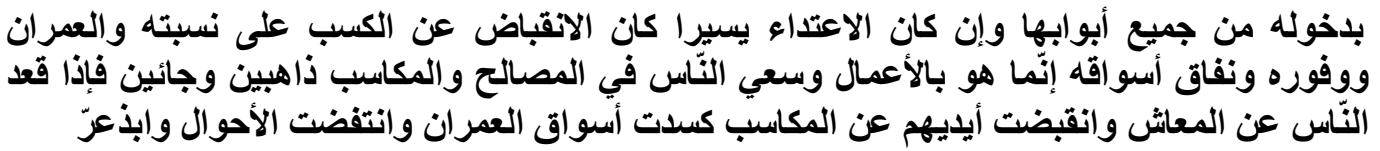

By entering it from all its doors, even though the assault was easy, the contraction was limited to earning, building, abundance, and hypocrisy of its markets, but it is going and coming through businesses and people seeking interests and gains.

The Economic Theory of Ibnu Khaldun in mapping a company able to compete to end unemployment includes:

1. Generating enthusiasm for work

2. Looking for work in accordance with its capabilities

3. It has a strong willingness to advance and prosper life

4. Do what can be done at that time.

This theory basically has an assumption that education can potentially have economic success if it is supported by its ability to produce expertise. Ibn Khaldun prefers the existence of good communication skills (fatqul lisan) to understand a job or trade. Quite relevant if sociology Ibn Khaldun's theory is seen from Critical Sociological Theory (Critical Sociology) to reduce unemployment of learners. This theory is more prioritizing the attitude of education that must be felt at all levels of society, its ability must also be possessed in the form of hard skills so as not to be undermined by technological progress. Achievement of skills these will not be achieved if you do not understand the condition of students as subjects. Students must know what they want by making it student oriented. That way, the achievements will be more leverage to get success in the end.

This approach, according to Ibn Khaldun's experience, is better to reduce unemployment, which in the end will avoid the decline of civilization. Proven in

\footnotetext{
${ }^{28}$ Harliana Halim et al., "The Principal Thinking of Ibn Khaldun: An Analysis on the Contribution to the Development of Contemporary Science," in Proceedings of The International Conference on Social Sciences (ICSS), vol. 1, 2018.

${ }^{29}$ Aliah B. Purwakania Hasan and Hendri Tanjung, "Islamic Religious Based Mental Health Education: Developing Framework for Indonesia Mental Health Policy Analysis.," in 8th International Conference of Asian Association of Indigenous and Cultural Psychology (ICAAIP 2017) (Atlantis Press, 2017).

${ }^{30}$ Ibn Khaldun, Diwan Al-Mubtada Wa Al-Khaba Fi Tarikh Al-'Arab Wa Al-Barbar Wa Man 'Asarahum Min Dzawi Al-Sha'ni Al-Akbar, 708.
} 
Tunisia at that time experienced rapid progress in terms of civilization in the world of education and economics.

\section{Conclusion}

The research shows that people naturally already have the skills and expertise they want to train and reinforce. That will is based on the knowledge or learning they enjoy. On the contrary, human beings will find it difficult if the system of education forces him to become a robot, to follow what is being asked without knowing what the benefits are for him. Ibn Khaldun's ability to communicate in various languages and Ibn Khaldun 's knowledge of soft skills and hard skills about the dignity of religious scholarship is very strong in the world of work although it is not in a formal school setting. Fatqu al-Lisan theory provided shows that there is a link between mind, language, and heart to communicate well and have essential skills, which can change life for the better on an economic basis.

\section{Bibliography}

Abdellah, Antar, and Abdelbaset Haridy. "Medieval Muslim Thinkers on Foreign Language Pedagogy: The Case of Ibn Khaldun.” Lingua 193 (July 1, 2017): 62-71. https://doi.org/10.1016/j.lingua.2017.05.001.

"Badan Pusat Statistik." Accessed June 16, 2020. https://www.bps.go.id/pressrelease/2019/11/05/1565/agustus-2019--tingkatpengangguran-terbuka--tpt--sebesar-5-28-persen.html.

Beck, Herman L. "Islam in Indonesia. The Contest for Society, Ideas and Values, Written by Carool Kersten." Bijdragen Tot de Taal-, Land-En Volkenkunde/Journal of the Humanities and Social Sciences of Southeast Asia 172, no. 4 (2016): 571-572.

Budiman, M. Nasir, and Saifullah Idris. "Between Religion and Education in Freud Perspective." Advanced Science Letters 24, no. 10 (2018): 7090-7094.

Cezzar, Juliette. "Teaching the Designer of Now: A New Basis for Graphic and Communication Design Education." She Ji: The Journal of Design, Economics, and Innovation, Design Education. Part II, 6, no. 2 (June 1, 2020): 213-27. https://doi.org/10.1016/j.sheji.2020.05.002.

Chabane, Djamel. "The Structure of 'Umran al-'Alam of Ibn Khaldun.” The Journal of North African Studies 13, no. 3 (2008): 331-349. https://doi.org/10.108o/13629380701844656.

Chapra, M. Umer. “Ibn Khaldun's Theory of Development: Does It Help Explain the Low Performance of the Present-Day Muslim World?" Journal of Socio$\begin{array}{lllll}\text { Economics } & 37, & \text { no. } & 2 & \text { (2008): }\end{array}$ https://doi.org/10.1016/j.socec.2006.12.051.

Dajani, Basma Ahmad Sedki. "The Ideal Education in Ibn Khaldun's Muqaddimah." Procedia - Social and Behavioral Sciences, The Proceedings of and Global Conference on Conference on Linguistics and Foreign Language Teaching, 192 (June 24, 2015): 308-12. https://doi.org/10.1016/j.sbspro.2015.06.044.

Decosimo, David. "Political Freedom as an Islamic Value." Journal of the American Academy of Religion 86, no. 4 (2018): 912-952. 
Dwivedi, Yogesh K., D. Laurie Hughes, Crispin Coombs, Ioanna Constantiou, Yanqing Duan, John S. Edwards, Babita Gupta, et al. "Impact of COVID-19 Pandemic on Information Management Research and Practice: Transforming Education, Work and Life." International Journal of Information Management, July 31, 2020, 102211. https://doi.org/10.1016/j.ijinfomgt.2020.102211.

Greenblatt, Stephen. The Rise and Fall of Adam and Eve. W. W. Norton \& Company, 2017.

Hafidzi, Anwar. "Dampak Dari Penetapan UU Nomor 26 Tahun 2000 Terhadap Kejahatan Kemanusiaan Dan Genosida Di Indonesia." Syariah: Jurnal Hukum Dan Pemikiran 15, no. 2 (2015).

-_- "Konsep Pendidikan Kemasyarakatan Ibnu Khaldun Dalam Kitab Muqaddimah," 2019.

Halim, Harliana, Hani Suraya Aziz, Khairul Azman Mohd Suhaimy, Fauziah Ani, Lutfan Jaes, Shakila Ahmad, Zahrul Akmal Damin, and Sharifah Khadijah Syed Abu Bakar. "The Principal Thinking of Ibn Khaldun: An Analysis on the Contribution to the Development of Contemporary Science." In Proceedings of The International Conference on Social Sciences (ICSS), Vol. 1, 2018.

Harwood, Stephen, and Sally Eaves. "Conceptualising Technology, Its Development and Future: The Six Genres of Technology." Technological Forecasting and Social Change $160 \quad$ (November 1, 2020): 120174. https://doi.org/10.1016/j.techfore.2020.120174.

Hasan, Aliah B. Purwakania, and Hendri Tanjung. "Islamic Religious Based Mental Health Education: Developing Framework for Indonesia Mental Health Policy Analysis." In 8th International Conference of Asian Association of Indigenous and Cultural Psychology (ICAAIP 2017). Atlantis Press, 2017.

Hassan, Aminuddin, Asmawati Suhid, Norhasni Zainal Abiddin, Habsah Ismail, and Haziyah Hussin. "The Role of Islamic Philosophy of Education in Aspiring Holistic Learning.” Procedia - Social and Behavioral Sciences, WCPCG 2010, 5 (January 1, 2010): 2113-18. https://doi.org/10.1016/j.sbspro.2010.07.423.

Houten, Maarten Matheus van. "Vocational Education and the Binary Higher Education System in the Netherlands: Higher Education Symbiosis or Vocational Education Dichotomy?" Journal of Vocational Education $\mathcal{E}$ Training 70, no. 1 (2018): 130-147.

Ibn Khaldūn. An Arab Philosophy of History; Selections from the Prolegomena of Ibn Khaldun of Tunis. London: Murray, 1950.

Ibn Khaldun, Muhammad. Diwan Al-Mubtada Wa Al-Khaba Fi Tarikh Al-'Arab Wa Al-Barbar Wa Man 'Asarahum Min Dzawi Al-Sha'ni Al-Akbar. Lebanon: DarFikr, 1998.

Ivanov, Igor, Jesennia Cárdenas Cobo, and Marina Kosonogova. "Implementation of Developmental Education in the Digital Learning Environment." Procedia Computer Science, 9th World Engineering Education Forum (WEEF 2019) Proceedings : Disruptive Engineering Education for Sustainable Development, 172 (January 1, 2020): 517-22. https://doi.org/10.1016/j.procs.2020.05.062.

K. Hitti, Philip. History of the Arabs, . Jakarta: Serambi Ilmu, 2006. 


\section{Anwar Hafidzi}

The Ideal Education in Ibnu Kholdun's

Memmi, Daniel. "Comparative Foundations of Eastern and Western Thought." AI $\mathcal{E}$ SOCIETY 32, no. 3 (2017): 359-368.

Meyer, Michael W., and Don Norman. "Changing Design Education for the 21st Century." She Ji: The Journal of Design, Economics, and Innovation, Design Education. Part I, 6, no. 1 (March 1, 2020): 13-49. https://doi.org/10.1016/j.sheji.2019.12.002.

Rahmawati, Anis. "Literacy Practice in Vocational Engineering Education: Is It Necessary?(A Case Study on the Concrete Construction Course)." In International Conference on Teacher Training and Education 2017 (ICTTE 2017). Atlantis Press, 2017.

Sahin, Abdullah. "Critical Issues in Islamic Education Studies: Rethinking Islamic and Western Liberal Secular Values of Education.” Religions 9, no. 11 (2018): 335 .

Salame, Issa I., and Ashley Thompson. "Students' Views on Strategic Note-Taking and Its Impact on Performance, Achievement, and Learning." International Journal of Instruction 13, no. 2 (2020): 1-16.

Suyitno, Imam, Gatut Susanto, Musthofa Kamal, and Ary Fawzi. "Teaching Materials and Techniques Needed by Foreign Students in Learning Bahasa Indonesia." ISLLAC: Journal of Intensive Studies on Language, Literature, Art, and Culture 1, no. 1 (2017): 52-70.

Wilde, Danielle. "Design Research Education and Global Concerns,." She Ji: The Journal of Design, Economics, and Innovation, Design Education. Part II, 6, no. 2 (June 1, 2020): 170-212. https://doi.org/10.1016/j.sheji.2020.05.003. 